\title{
Synthesis and Characterization with Antineoplastic, Biochemical, Cytotoxic, and Antimicrobial Studies of Schiff Base Cu(II) Ion Complexes
}

\author{
M. M. Haque, Md. Kudrat-E-Zahan, Laila Arjuman Banu, \\ Md. Shariful Islam, and M. S. Islam \\ Inorganic Research Laboratory, Department of Chemistry, University of Rajshahi, Rajshahi 6205, Bangladesh \\ Correspondence should be addressed to Md. Kudrat-E-Zahan; kudrat.chem@ru.ac.bd
}

Received 3 April 2015; Revised 26 June 2015; Accepted 12 July 2015

Academic Editor: Guillermo Mendoza-Diaz

Copyright ( 2015 M. M. Haque et al. This is an open access article distributed under the Creative Commons Attribution License, which permits unrestricted use, distribution, and reproduction in any medium, provided the original work is properly cited.

Copper(II) complexes containing two Schiff base ligands derived from 2-hydroxybenzaldehyde with 2-aminophenol and 3aminophenol have been synthesized and characterized by means of analytical, magnetic, and spectroscopic methods. Bacteria, fungus, Entamoeba histolytica, and antineoplastic activities of the synthesized complexes have been determined by monitoring the parameters cell growth inhibition, survival time of tumour mice, time-body relation, causing of intraperitoneal cells and macrophages, alkaline phosphatase activity, hematological effect, and biopsy of tumour.

\section{Introduction}

Schiff base metal complexes based research works have been widely carried out from 1930, because of their biological and industrial applications [1-5]. The use of metal complexes as pharmaceuticals has shown promise in recent years particularly as anticancer agents [6]. Previously, synthesis and properties of thiocyanato complex of low valent metal ions containing different monodentate auxiliary ligands have been reported from our laboratory [7-9]. Worldwide spread of drug-resistant bacteria is now a critical problem in global health. To find new drug, recently, we studied few mixedligand complexes containing heterocyclic amine as secondary ligands and few Schiff base containing complexes [10-12]. In present study, mixed-ligand complexes of $\mathrm{Cu}(\mathrm{II})$ containing the Schiff base ligand derived from 2-hydroxybenzaldehyde with 2-aminophenol/3-aminophenol and bidentate auxiliary ligands were synthesized and characterized. The auxiliary ligands used were potassium thiocyanato, 2-aminopyridine, and 2-phenylenediamine. Antineoplastic, biochemical, cytotoxic, and antimicrobial activities of the complexes were also studied.

\section{Experimental}

2.1. Physical Measurement. The weighing operation was performed on a METTLER PM-200 electronic balance. Conductivity measurements were carried out in dimethyl sulfoxide (DMSO) using a WPACMS 35 conductivity meter and dipcell with platinized electrodes. The melting or decomposition temperatures of all the prepared metal complexes were observed in an electrothermal melting point apparatus model number AZ6512. The SHERWOOD SCIENTIFIC Magnetic Susceptibility Balance was used for the present investigation. Infrared spectra as $\mathrm{KBr}$ disc were recorded in a SIMADZU FTIR-8400 (Japan) infrared spectrophotometer, from 4000 to $400 \mathrm{~cm}^{-1}$. The absorbances of the complexes were recorded on SHIMUDZU Spectrophotometer. Analyses of the complexes for carbon, hydrogen, and nitrogen were carried out by Microanalytical Services at the University of St. Andrews, Scotland. Transplantable tumour (Ehrlich's Ascites Carcinoma, EAC) used in this research was obtained from Indian Institute of Chemical Biology (IICB), Calcutta, India. In vivo antineoplastic activity of the test complexes was determined by measuring the effect of the test complexes 
TABLE 1: Analytical data and physical properties.

\begin{tabular}{|c|c|c|c|c|c|c|c|c|c|}
\hline Complex notation & Complex & Colour & $\begin{array}{c}\text { Melting } \\
\text { point }\left({ }^{\circ} \mathrm{C}\right)\end{array}$ & $\% \mathrm{M}$ & $\% \mathrm{C}$ & $\% \mathrm{H}$ & $\% \mathrm{~N}$ & $\begin{array}{l}\text { Molar conductance } \\
\left(\mathrm{Ohm}^{1} \mathrm{~cm}^{2} \mathrm{~mol}^{-1}\right)\end{array}$ & $\begin{array}{c}\text { Magnetic } \\
\text { moment } \\
M_{\text {eff }} \text { (B.M) }\end{array}$ \\
\hline A & $\mathrm{K}[\mathrm{Cu}(\mathrm{SB}-1)(\mathrm{SCN})]$ & Yellowish & $175-177$ & & $\begin{array}{c}45.22 \\
(45.18)\end{array}$ & $\begin{array}{c}2.42 \\
(2.39) \\
\end{array}$ & $\begin{array}{c}7.53 \\
(7.50) \\
\end{array}$ & 29 & 1.95 \\
\hline B & $\begin{array}{c}{[\mathrm{Cu}(\mathrm{SB}-2) \mathrm{NN}]} \\
\mathrm{NN}=\text { aminopyridine }\end{array}$ & Greenish & $228-230$ & $\begin{array}{c}17.14 \\
(17.52)\end{array}$ & $\begin{array}{c}58.27 \\
(58.60)\end{array}$ & $\begin{array}{c}4.05 \\
(4.50)\end{array}$ & $\begin{array}{c}11.33 \\
(11.10)\end{array}$ & 35 & 1.90 \\
\hline $\mathrm{C}$ & $\begin{array}{c}{[\mathrm{Cu}(\mathrm{SB}-2) \mathrm{NN}]} \\
\mathrm{NN}= \\
\text { phenylenediamine }\end{array}$ & Greenish & $160-162$ & $\begin{array}{c}16.52 \\
(16.05)\end{array}$ & $\begin{array}{c}59.27 \\
(58.89)\end{array}$ & $\begin{array}{c}4.42 \\
(4.10)\end{array}$ & $\begin{array}{c}10.92 \\
(10.50)\end{array}$ & 42 & 2.0 \\
\hline
\end{tabular}

${ }^{a}$ The values found are given in parenthesis.

TABLE 2: Selected IR spectral data of the complexes (band maxima, $\mathrm{cm}^{-1}$ ).

\begin{tabular}{|c|c|c|c|c|c|c|c|}
\hline Compound & $\nu(\mathrm{C}=\mathrm{N})$ & $\nu\left(\mathrm{NH}_{2}\right)$ & $v(\mathrm{CS})$ & $\nu(\mathrm{M}-\mathrm{O})$ & $v(\mathrm{M}-\mathrm{N})$ & $v(\mathrm{M}-\mathrm{S}-\mathrm{C}=\mathrm{N})$ & Others \\
\hline $\mathrm{K}[\mathrm{Cu}(\mathrm{SB}-1)(\mathrm{SCN})]$ & 1605 & & 750 & 535 & 415 & 340 & $\nu(\mathrm{C}=\mathrm{N})=2100$ \\
\hline $\begin{array}{l}\mathrm{Cu}(\mathrm{SB}-2) \mathrm{NN}] \\
\mathrm{C}_{18} \mathrm{H}_{17} \mathrm{O}_{2} \mathrm{CuN}_{3}\end{array}$ & & $\begin{array}{l}3290 \\
3150 \\
\end{array}$ & & 537 & 295 & & $\nu(\mathrm{C}=\mathrm{N})=1555$ \\
\hline $\begin{array}{l}\mathrm{Cu}(\mathrm{SB}-2) \mathrm{NN}] \\
\mathrm{C}_{19} \mathrm{H}_{17} \mathrm{O}_{2} \mathrm{CuN}_{3} \\
\end{array}$ & & $\begin{array}{l}3315 \\
3232 \\
\end{array}$ & & 535 & 285 & & \\
\hline
\end{tabular}

TABLE 3: Electronic spectral data of the complexes (band maxima in $\left.\mathrm{cm}^{-1}\right)$.

\begin{tabular}{lccc}
\hline Compound & Band I & Band II & Band III \\
\hline $\mathrm{K}[\mathrm{Cu}(\mathrm{SB}-1)(\mathrm{SCN})]$ & 15,267 & 19,157 & 22,000 \\
\hline$[\mathrm{Cu}(\mathrm{SB}-2) \mathrm{NN}]$ & 15,395 & 19,500 & 24,000 \\
$\mathrm{C}_{18} \mathrm{H}_{17} \mathrm{O}_{2} \mathrm{CuN}_{3}$ & & & \\
\hline$[\mathrm{Cu}(\mathrm{SB}-2) \mathrm{NN}]$ & 15,400 & 19,890 & 23,995 \\
\hline $\mathrm{C}_{19} \mathrm{H}_{17} \mathrm{O}_{2} \mathrm{CuN}_{3}$ & & & \\
\hline
\end{tabular}

on tumour cell growth inhibition, survival time of tumour bearing mice, hematological parameters, and serum alkaline phosphatase activity of tumour bearing mice. Tumour growth was monitored by recording daily weight change. The concentration of haemoglobin was measured by the usual procedure using Sahli's haemometer.

2.2. Procedure of Preparation of Schiff Base (SB-1). The Schiff bases were prepared by the condensation of 2hydroxybenzaldehyde with 2-aminophenol. 2-Hydroxybenzaldehyde $(1.7 \mathrm{~g}, 0.014 \mathrm{~mol})$ in absolute ethanol $(20 \mathrm{~mL})$ was added to an ethanolic $(30 \mathrm{~mL})$ solution of 2 -aminophenol $(1.5 \mathrm{~g}, 0.014 \mathrm{~mol})$. The mixture was heated to reduce the volume to $25 \mathrm{~mL}$, and then it was cooled in an ice-bath. The black crystalline product was isolated and washed with hot ethanol. The structure of SB-1 is shown in Figure 1.

2.2.1. Procedure of Preparation of Test Compound K[Cu(SB1) $(\mathrm{SCN})], \mathrm{SB}-1=\mathrm{C}_{13} \mathrm{H}_{9} \mathrm{NO}_{2}$. An appropriate solution of $\mathrm{CuCl}_{2} \cdot \mathrm{H}_{2} \mathrm{O}(0.005 \mathrm{~mol})$ in absolute ethanol $(25 \mathrm{~mL})$ was added to an ethanolic $(30 \mathrm{~mL})$ solution of potassium thiocyanate $(0.005 \mathrm{~mol})$. The solution was filtered and the filtrate<smiles>Oc1ccccc1/C=N/c1ccccc1O</smiles>

FIGURE 1: (2-Hydroxy-benzylidene)-(2-hydroxy-phenyl)-amine (SB-1). Yield: $3.0 \mathrm{~g}$ (78\%). Anal. Calc. (\%): C, 73.2; H, 5.2; N, 6.6. Found: C, 73.1; H, 5.1; N, 6.7. M.p. $160-162^{\circ} \mathrm{C}$.

was added to the methanolic solution of $\mathrm{C}_{13} \mathrm{H}_{9} \mathrm{NO}_{2} \mathrm{H}_{2}$ (SB1) $(0.005 \mathrm{~mol}, 80 \mathrm{~mL})$. The resulting mixture was boiled on a water bath for 5 minutes and cooled. The complexes were separated, washed with hot ethanol, and dried in vacuo over $\mathrm{P}_{4} \mathrm{O}_{10}$.

2.3. Procedure of Preparation of Schiff Base (SB-2). The Schiff base was prepared by the condensation of 2hydroxybenzaldehyde with 3-aminophenol. 2-Hydroxybenzaldehyde $(1.7 \mathrm{~g}, 0.014 \mathrm{~mol})$ in absolute methanol $(20 \mathrm{~mL})$ was added to an ethanolic solution $(30 \mathrm{~mL})$ of 3 -aminophenol $(1.5 \mathrm{~g}, 0.014 \mathrm{~mol})$. The mixture was heated to reduce the volume to $25 \mathrm{~mL}$ and then it was cooled in an ice-bath. The black crystalline product was filtered and washed with hot ethanol. The structure of SB-2 is shown in Figure 2.

2.3.1. Procedure of Preparation for $[\mathrm{Cu}(\mathrm{SB}-2)(\mathrm{NN})][\mathrm{NN}=2$ Aminopyridine/2-Phenylenediamine]. $25 \mathrm{~mL}$ of an ethanolic solution of the metal chloride $(0.005 \mathrm{~mol})\left[\mathrm{CuCl}_{2} \cdot \mathrm{H}_{2} \mathrm{O}\right]$ was added to $30 \mathrm{~mL}$ of an ethanolic solution of the above prepared Schiff base $(1.05 \mathrm{~g}, 0.005 \mathrm{~mol})$. Then $20 \mathrm{~mL}$ of an ethanolic 
TABLE 4: The effect of test compounds and bleomycin on EAC cell growth inhibition.

\begin{tabular}{|c|c|c|c|c|}
\hline Experiment & Drugs & Dose & $\begin{array}{c}\text { Number of EAC } \\
\text { cells/mouse on } 5 \text { th day after } \\
\text { tumour (EAC) cell } \\
\text { inoculation }\end{array}$ & $\%$ of cell growth inhibition \\
\hline EAC & & & $(9.61 \pm 1.63) \times 10^{7}$ & \\
\hline EAC + bleomycin & & $0.3 \mathrm{mg} / \mathrm{kg}$ & $(0.49 \pm 0.77) \times 10^{7}$ & 94.90 \\
\hline A & Synthetic & $8 \mathrm{mg} / \mathrm{kg}$ & $(0.46 \pm 0.62) \times 10^{7}$ & 95.21 \\
\hline $\mathrm{B}$ & Synthetic & $10 \mathrm{mg} / \mathrm{kg}$ & $(1.21 \pm 0.32) \times 10^{7}$ & 87.40 \\
\hline $\mathrm{C}$ & Synthetic & $16 \mathrm{mg} / \mathrm{kg}$ & $(1.01 \pm 0.78) \times 10^{7}$ & 89.49 \\
\hline
\end{tabular}

$\mathrm{A}=\mathrm{K}[\mathrm{Cu}(\mathrm{SB}-1)(\mathrm{SCN})], \mathrm{B}=[\mathrm{Cu}(\mathrm{SB}-2) \mathrm{NN}], \mathrm{NN}=2$-aminopyridine, and $\mathrm{C}=[\mathrm{Cu}(\mathrm{SB}-2)(\mathrm{NN})], \mathrm{NN}=$ 2-phenylenediamine.

TABLE 5: The effect of test compounds on survival time of EAC cell bearing mice.

\begin{tabular}{lcccc}
\hline Name of experiment & Drugs & Dose & Mean survival time & \% of increase life span \\
\hline Control (EAC bearing mice) & & & $(21.37 \pm 1.7)$ & $40 \pm 1.2$ \\
EAC + bleomycin & & $0.3 \mathrm{mg} / \mathrm{kg}$ & $29 \pm 2.6$ & 35.17 \\
A & Synthetic & $8 \mathrm{mg} / \mathrm{kg}$ & $25 \pm 1.4$ & 16.98 \\
B & Synthetic & $10 \mathrm{mg} / \mathrm{kg}$ & $26.14 \pm 1.1$ & 22.32 \\
C & Synthetic & $16 \mathrm{mg} / \mathrm{kg}$ & \\
\hline
\end{tabular}

$\mathrm{A}=\mathrm{K}[\mathrm{Cu}(\mathrm{SB}-1)(\mathrm{SCN})], \mathrm{B}=[\mathrm{Cu}(\mathrm{SB}-2) \mathrm{NN}], \mathrm{NN}=2$-aminopyridine, and $\mathrm{C}=[\mathrm{Cu}(\mathrm{SB}-2)(\mathrm{NN})], \mathrm{NN}=2$-phenylenediamine.

TABLE 6: The effect of test compounds on survival time of EAC cell bearing mice.

\begin{tabular}{|c|c|c|c|c|c|c|}
\hline Days & Control (EAC) & $\begin{array}{c}\text { Bleomycin } \\
(0.3 \mathrm{mg} / \mathrm{kg} \text { i.p. })\end{array}$ & $\begin{array}{c}\text { DMSO } \\
25 \mathrm{mg} / \mathrm{kg}\end{array}$ & $\begin{array}{c}\mathrm{A} \\
8 \mathrm{mg} / \mathrm{kg}\end{array}$ & $\begin{array}{c}\mathrm{B} \\
10 \mathrm{mg} / \mathrm{kg} \\
\end{array}$ & $\begin{array}{c}\mathrm{C} \\
16 \mathrm{mg} / \mathrm{kg}\end{array}$ \\
\hline 0 & 00 & 00 & 00 & 00 & 00 & 00 \\
\hline 2 & $0.77 \pm 0.37$ & $0.57 \pm 0.17$ & $0.76 \pm 0.38$ & $0.55 \pm 0.13$ & $0.64 \pm 0.19$ & $0.60 \pm 0.26$ \\
\hline 4 & $0.98 \pm 0.43$ & $0.75 \pm 0.22$ & $0.97 \pm 0.63$ & $0.72 \pm 0.22$ & $0.84 \pm 0.24$ & $0.82 \pm 0.17$ \\
\hline 6 & $1.30 \pm 0.27$ & $1.10 \pm 0.24$ & $1.31 \pm 0.33$ & $1.06 \pm 0.24$ & $1.21 \pm 0.16$ & $1.16 \pm 0.31$ \\
\hline 8 & $1.54 \pm 0.32$ & $1.24 \pm 0.14$ & $1.57 \pm 0.23$ & $1.14 \pm 0.12$ & $1.37 \pm 0.16$ & $1.31 \pm 0.14$ \\
\hline 10 & $1.78 \pm 0.18$ & $1.44 \pm 0.30$ & $1.76 \pm 0.16$ & $1.29 \pm 0.19$ & $1.48 \pm 0.26$ & $1.43 \pm 0.22$ \\
\hline 12 & $2.13 \pm 0.17$ & $1.63 \pm 0.16$ & $2.14 \pm 0.17$ & $1.47 \pm 0.22$ & $1.77 \pm 0.18$ & $1.71 \pm 0.14$ \\
\hline 14 & $2.55 \pm 0.67$ & $1.80 \pm 0.23$ & $2.55 \pm 0.63$ & $1.73 \pm 0.32$ & $1.93 \pm 0.34$ & $1.84 \pm 0.18$ \\
\hline 16 & $3.94 \pm 0.55$ & $2.05 \pm 0.27$ & $3.93 \pm 0.53$ & $1.94 \pm 0.14$ & $2.17 \pm 0.12$ & $2.10 \pm 0.21$ \\
\hline 18 & $4.44 \pm 0.43$ & $2.20 \pm 0.15$ & $4.40 \pm 0.42$ & $2.13 \pm 0.12$ & $2.47 \pm 0.15$ & $2.29 \pm 0.23$ \\
\hline 20 & $5.13 \pm 0.63$ & $2.43 \pm 0.11$ & $5.14 \pm 0.62$ & $2.36 \pm 0.16$ & 2.73 & $2.49 \pm 0.44$ \\
\hline
\end{tabular}

$\mathrm{A}=\mathrm{K}[\mathrm{Cu}(\mathrm{SB}-1)(\mathrm{SCN})], \mathrm{B}=[\mathrm{Cu}(\mathrm{SB}-2) \mathrm{NN}], \mathrm{NN}=2$-aminopyridine, and $\mathrm{C}=[\mathrm{Cu}(\mathrm{SB}-2)(\mathrm{NN})], \mathrm{NN}=2$-phenylenediamine.

TABLE 7: The effect of test compounds on hematological parameters in normal and tumour bearing mice.

\begin{tabular}{|c|c|c|c|c|c|c|}
\hline Name of experiment & $\begin{array}{l}\text { HB level } \\
\text { g/dL }\end{array}$ & $\begin{array}{c}\mathrm{RBC} \\
\text { cell/mL }\end{array}$ & $\begin{array}{c}\text { WBC (TC) } \\
\text { cell/mL }\end{array}$ & Lymphocyte \% & Neutrophil \% & Monocyte \% \\
\hline Normal mice & $13.65 \pm 0.4$ & $(7.96 \pm 0.57) \times 10^{9}$ & $(6.35 \pm 0.26) \times 10^{6}$ & $71.25 \pm 0.91$ & $19.19 \pm 0.28$ & $8.93 \pm 0.23$ \\
\hline $\mathrm{N}+\mathrm{A}$ & $12.25 \pm 0.17$ & $(6.16 \pm 0.16) \times 10^{9}$ & $(10.76 \pm 0.17) \times 10^{6}$ & $75.00 \pm 0.83$ & $21.79 \pm 0.38$ & $3.10 \pm 0.34$ \\
\hline $\mathrm{N}+\mathrm{B}$ & $10.23 \pm 0.13$ & $(5.93 \pm 0.22) \times 10^{9}$ & $(16 \pm 0.23) \times 10^{6}$ & $72.10 \pm 0.34$ & $26.23 \pm 0.24$ & $1.73 \pm 0.17$ \\
\hline $\mathrm{N}+\mathrm{C}$ & $11.89 \pm 0.26$ & $(6.33 \pm 0.19) \times 10^{9}$ & $(14 \pm 0.23) \times 10^{6}$ & $73.47 \pm 0.83$ & $24.21 \pm 0.16$ & $2 \pm 0.21$ \\
\hline EAC (mice) & $7.11 \pm 0.23$ & $(2.40 \pm 0.10) \times 10^{9}$ & $(25.63 \pm 0.18) \times 10^{6}$ & $43.36 \pm 0.43$ & $38.23 \pm 0.37$ & $10 \pm 0.28$ \\
\hline $\mathrm{EAC}+\mathrm{A}$ & $11.25 \pm 0.23$ & $(6.04 \pm 0.21) \times 10^{9}$ & $(9.19 \pm 0.36) \times 10^{6}$ & $60.25 \pm 0.68$ & $26.65 \pm 0.18$ & $8 \pm 0.86$ \\
\hline $\mathrm{EAC}+\mathrm{B}$ & $10.14 \pm 0.18$ & $(5.62 \pm 0.27) \times 10^{9}$ & $(14.82 \pm 0.41) \times 10^{6}$ & $51.87 \pm 0.78$ & $34.11 \pm 0.22$ & $6.12 \pm 0.92$ \\
\hline $\mathrm{EAC}+\mathrm{C}$ & $10.34 \pm 0.10$ & $(5.89 \pm 0.29) \times 10^{9}$ & $(12.67 \pm 1.40) \times 10^{6}$ & $57.68 \pm 1.37$ & $33.20 \pm 2.8$ & $8.10 \pm 3.10$ \\
\hline
\end{tabular}

$\mathrm{A}=\mathrm{K}[\mathrm{Cu}(\mathrm{SB}-1)(\mathrm{SCN})], \mathrm{B}=[\mathrm{Cu}(\mathrm{SB}-2) \mathrm{NN}], \mathrm{NN}=2$-aminopyridine, and $\mathrm{C}=[\mathrm{Cu}(\mathrm{SB}-2)(\mathrm{NN})], \mathrm{NN}=2$-phenylenediamine. 
TABLE 8: The effect of test compounds on serum alkaline phosphatase activity.

\begin{tabular}{lccc}
\hline Name of experiment & $\begin{array}{c}\text { ALKP activity }(\mu \mathrm{mol} \text { of PNPP } \\
\text { hydrolyzed/min/mL serum })\end{array}$ & Name of experiment & $\begin{array}{c}\text { ALKP activity }(\mu \mathrm{mol} \text { of PNPP } \\
\text { hydrolyzed/min } / \mathrm{mL} \text { serum })\end{array}$ \\
\hline EAC & $(8.56 \pm 0.31) \times 10^{-3}$ & Normal value & $(28.33 \pm 0.71) \times 10^{-3}$ \\
EAC + DMSO & $(28.96 \pm 0.21) \times 10^{-3}$ & DMSO & $(29.13 \pm 0.14) \times 10^{-3}$ \\
EAC + A & $(22.11 \pm 0.46) \times 10^{-3}$ & $\mathrm{~N}+\mathrm{A}$ & $(38.33 \pm 0.27) \times 10^{-3}$ \\
EAC + B & $(16.93 \pm 0.49) \times 10^{-3}$ & $\mathrm{~N}+\mathrm{B}$ & $(35.11 \pm 0.45) \times 10^{-3}$ \\
EAC + C & $(19.88 \pm 0.88) \times 10^{-3}$ & $\mathrm{~N}+\mathrm{C}$ & $(32.79 \pm 0.67) \times 10^{-3}$ \\
\hline
\end{tabular}<smiles>Oc1cccc(/C=N/c2ccccc2O)c1</smiles>

Figure 2: (3-Hydroxy-benzylidene)-(2-hydroxy-phenyl)-amine (SB-2). Yield: 3.1 g (82\%). Anal. Calc. (\%): C, 73.2; H, 5.2; N, 6.6. Found: C, 73.0; H, 5.2; N, 6.5. M.p. $160-162^{\circ} \mathrm{C}$.

solution of [NN] $(0.005 \mathrm{~mol})$ was added to the metal saltSchiff base solution. The resulting mixture was boiled on a water bath for 5 minutes and after that it was cooled. The complexes that were separated were washed with hot ethanol and dried in vacuo over $\mathrm{P}_{4} \mathrm{O}_{10}$.

\section{Results and Discussion}

3.1. Elemental Analysis and Conductivity Measurement. The analytical data and physical properties of the synthesized complexes are given in Table 1. The molar conductances in DMSO indicate that the complexes are all 1:1 electrolytes $[13,14]$.

\subsection{IR Studies}

Complex A. The infrared spectral data are shown in Table 2. The Schiff base $\mathrm{C}_{13} \mathrm{H}_{9} \mathrm{NO}_{2} \mathrm{H}_{2}$ [SB-1] behaves as tridentate dinegative ligand coordinating at the imino nitrogen and two oxygen atoms. In the complexes, the shift of $v(\mathrm{C}=\mathrm{N})$ mode in a frequency $1605 \mathrm{~cm}^{-1}$ relative to the free ligand value $1610-1620 \mathrm{~cm}^{-1}$ (for ligand $\mathrm{C}_{13} \mathrm{H}_{9} \mathrm{NO}_{2}$ ) indicates that bond formation takes place through the imino nitrogen atom. The $\nu(\mathrm{OH})$ band observed in the free Schiff base (SB-1) disappears upon coordination, which indicates deprotonation and coordination at the oxygen sites. Furthermore, the presence of $v(\mathrm{M}-\mathrm{O})$ and $v(\mathrm{M}-\mathrm{N})$ linkages of bands at $455-535 \mathrm{~cm}^{-1}$, respectively, was observed for all the complexes (A) [15-17]. The ambidentate thiocyanate ligand can give either M-NCS or M-SCN bonding sequence, which nevertheless reveals the acidity of the metal ions. The complexes also display $v(\mathrm{CN})$ at $2100 \mathrm{~cm}^{-1}$ characteristic of S-bonded thiocyanato moieties. In Pearson's terminology, these are soft acids. The $v(\mathrm{CS})$ modes appear at lower frequencies in the $\mathrm{M}-\mathrm{S}-\mathrm{C}=\mathrm{N}$ complexes than those in the $\mathrm{M}-\mathrm{N}-\mathrm{C}=\mathrm{S}$ complexes $[8,9,18]$.
TABLE 9: The effect of test compounds on the enhancement of peritoneal cells and macrophages of life.

\begin{tabular}{lccc}
\hline $\begin{array}{l}\text { Name of the } \\
\text { experiment }\end{array}$ & $\begin{array}{c}\text { Dose } \\
\mathrm{mg} / \mathrm{kg}\end{array}$ & $\begin{array}{c}\text { Total peritoneal } \\
\text { macrophage cells } \\
\left(\times 10^{6}\right) / \text { mouse } \\
\text { Mean } \pm \text { SEM }\end{array}$ & $\begin{array}{c}\text { Total peritoneal } \\
\text { cells } \\
\left(\times 10^{6}\right) / \text { mouse } \\
\text { Mean } \pm \text { SEM }\end{array}$ \\
\hline Normal & Tap water & $3.23 \pm 2.0$ & $23.76 \pm 0.321$ \\
A & 8 & $5.23 \pm 0.40$ & $25.42 \pm 0.66$ \\
B & 10 & $4.10 \pm 0.62$ & $25.93 \pm 0.19$ \\
C & 16 & $4.91 \pm 0.52$ & $26.71 \pm 0.44$ \\
\hline
\end{tabular}

$\mathrm{A}=\mathrm{K}[\mathrm{Cu}(\mathrm{SB}-1)(\mathrm{SCN})], \mathrm{B}=[\mathrm{Cu}(\mathrm{SB}-2) \mathrm{NN}], \mathrm{NN}=2$-aminopyridine, and $\mathrm{C}=[\mathrm{Cu}(\mathrm{SB}-2)(\mathrm{NN})], \mathrm{NN}=2$-phenylenediamine.

TABLE 10: The effect of test compounds on generation of MDA by lipid peroxidation in serum of normal mice.

\begin{tabular}{lc}
\hline Name of the experiment & $\mathrm{mmol} \mathrm{MDA} / \mathrm{mL}$ serum \\
\hline Normal mice (control) & $6.71 \pm 0.32$ \\
$\mathrm{~A}$ & $11.43 \pm 0.67$ \\
$\mathrm{~B}$ & $10.11 \pm 0.20$ \\
$\mathrm{C}$ & $10.94 \pm 0.39$ \\
\hline
\end{tabular}

$\mathrm{A}=\mathrm{K}[\mathrm{Cu}(\mathrm{SB}-1)(\mathrm{SCN})], \mathrm{B}=[\mathrm{Cu}(\mathrm{SB}-2) \mathrm{NN}], \mathrm{NN}=2$-aminopyridine, and $\mathrm{C}=[\mathrm{Cu}(\mathrm{SB}-2)(\mathrm{NN})], \mathrm{NN}=2$-phenylenediamine.

The band of $v(\mathrm{CS})$ at $750 \mathrm{~cm}^{-1}$ is characteristic of $\mathrm{M}$ $\mathrm{S}-\mathrm{C}=\mathrm{N}$ bonding sequence. This is further apparent from the $v(\mathrm{M}-\mathrm{S})$ modes at $350 \mathrm{~cm}^{-1}$ in the far infrared spectra of the complexes.

Compounds $B$ and $C$. The free Schiff base ligand shows characteristic bands at $3530 \mathrm{~cm}^{-1}$ for $\nu(\mathrm{OH})$ and $1607 \mathrm{~cm}^{-1}$ for $v(\mathrm{C}=\mathrm{N})$. In the complexes, $\nu(\mathrm{C}=\mathrm{N})$ of the Schiff base ligand remains practically unchanged showing that the imino nitrogen does not participate in bonding. The IR spectrum of free 2-phenylenediamine shows $v\left(\mathrm{NH}_{2}\right)$ modes at 3400 and $3378 \mathrm{~cm}^{-1}$, respectively. These bands are also shifted to lower frequencies in the complexes $(\mathrm{B}, \mathrm{C})\left(3315,3232 \mathrm{~cm}^{-1}\right)$ indicating coordination by the amino nitrogen but appear at $3290 \mathrm{~cm}^{-1}$ and $3150 \mathrm{~cm}^{-1}$ in compound $\mathrm{B}$. This is also evident from the appearance of bands at $285-310 \mathrm{~cm}^{-1}$ which are tentatively attributed to the $v(\mathrm{M}-\mathrm{N})$ mode. Further, in complexes with 2-aminopyridine (B), the $v(\mathrm{C}=\mathrm{N})$ mode appears at $1555 \mathrm{~cm}^{-1}$ indicating that the ring nitrogen is coordinated to the metal atom. 
TABLE 11: Histopathological effect of test compounds.

\begin{tabular}{lcccc}
\hline Name of the experiment & & & Observation & \\
& Size & Number of lymphocytes & Necrotic area & Inflammatory area \\
\hline EAC & $\uparrow \uparrow \uparrow$ & $\downarrow \downarrow \downarrow$ & $\uparrow \uparrow \uparrow$ & $\uparrow \uparrow \uparrow$ \\
A & $\downarrow \downarrow \downarrow$ & $\uparrow \uparrow \uparrow$ & $\uparrow$ & $\uparrow$ \\
B & $\downarrow$ & $\uparrow$ & $\uparrow \uparrow$ & $\uparrow \uparrow$ \\
C & $\downarrow \downarrow$ & $\uparrow \uparrow$ & $\uparrow \uparrow \uparrow$ & $\uparrow \uparrow \uparrow$ \\
Bleomycin & $\downarrow \downarrow \downarrow$ & $\uparrow \uparrow \uparrow$ &
\end{tabular}

$\mathrm{A}=\mathrm{K}[\mathrm{Cu}(\mathrm{SB}-1)(\mathrm{SCN})], \mathrm{B}=[\mathrm{Cu}(\mathrm{SB}-2) \mathrm{NN}], \mathrm{NN}=2$-aminopyridine, and $\mathrm{C}=[\mathrm{Cu}(\mathrm{SB}-2)(\mathrm{NN})], \mathrm{NN}=2$-phenylenediamine.

$\uparrow=$ increase, $\uparrow \uparrow=$ moderately increase, and $\uparrow \uparrow \uparrow=$ greatly increase.

$\downarrow=$ decrease, $\downarrow \downarrow$ = moderately decrease, and $\downarrow \downarrow \downarrow$ = greatly decrease.

TABLE 12: Effect of test compounds on total protein in peritoneal fluid.

\begin{tabular}{lcc}
\hline Name of the complex & Dose $(\mathrm{mg} / \mathrm{kg})$ & $\begin{array}{l}\text { Total protein } \\
\text { mg/mL, P.F., } \\
\text { mean } \pm \text { SEM }\end{array}$ \\
\hline Control (EAC) & Tap water & $174.73 \pm 2.81$ \\
A & 8 & $165.22 \pm 2.93$ \\
B & 10 & $167.33 \pm 3.23$ \\
C & 10 & $166.97 \pm 3.20$
\end{tabular}

$\mathrm{A}=\mathrm{K}[\mathrm{Cu}(\mathrm{SB}-1)(\mathrm{SCN})], \mathrm{B}=[\mathrm{Cu}(\mathrm{SB}-2) \mathrm{NN}], \mathrm{NN}=2$-aminopyridine, and $\mathrm{C}=[\mathrm{Cu}(\mathrm{SB}-2)(\mathrm{NN})], \mathrm{NN}=2$-phenylenediamine.

TABLE 13: Zone of inhibition of antifungal activity of test complexes.

\begin{tabular}{lcccc}
\hline Test fungus & \multicolumn{4}{c}{$\begin{array}{c}\text { Diameter of zone of inhibition } \\
(\mathrm{mm})\end{array}$} \\
& $\mathrm{A}$ & $\mathrm{B}$ & $\mathrm{C}$ & $\begin{array}{c}\text { Nystatin } \\
(45 \mu \mathrm{g} / \mathrm{disc})\end{array}$ \\
\hline Tinea pedis & 4 & 2 & 3 & 18 \\
Aspergillus niger & 8 & 23 & 10 & 28 \\
Coniothyrium sp. & 22 & 6 & 8 & 20 \\
\hline
\end{tabular}

$\mathrm{A}=\mathrm{K}[\mathrm{Cu}(\mathrm{SB}-1)(\mathrm{SCN})], \mathrm{B}=[\mathrm{Cu}(\mathrm{SB}-2) \mathrm{NN}], \mathrm{NN}=2$-aminopyridine, and $\mathrm{C}$ $=[\mathrm{Cu}(\mathrm{SB}-2)(\mathrm{NN})], \mathrm{NN}=2$-phenylenediamine.

3.3. Magnetic Moment and Electronic Spectra. The effective magnetic moments and electronic spectral components are shown in Tables 1 and 3. All the complexes are paramagnetic and show magnetic moment between 1.90 and 2.00 B.M corresponding to one unpaired electron. In electronic spectra three bands were observed at around 15455, 19500, and $22172 \mathrm{~cm}^{-1}$ corresponding to the transitions, ${ }^{2} \mathrm{~B}_{1 \mathrm{~g}}$ to ${ }^{2} \mathrm{~A}_{1 \mathrm{~g}}$, ${ }^{2} \mathrm{~B}_{1 \mathrm{~g}}$ to ${ }^{2} \mathrm{E}_{\mathrm{g}}$, and charge transfer, respectively. These bands are consistent with square planar geometry [19].

\section{Antineoplastic Activity of the Test Compounds}

4.1. The Effect of Test Compounds and Bleomycin on Ehrlich Ascites Carcinoma (EAC) Cell Growth Inhibition. Treatment with test compounds resulting in maximum cell growth inhibition on compounds $\mathrm{A}, \mathrm{B}$, and $\mathrm{C}$ as evident from $95.21 \%, 87.40 \%$, and $89.49 \%$, reduction of tumour cell, which was found to be equivalent to standard or nearly standard
TABLE 14: The summary of the results of minimum inhibitory concentration (MIC) of test complexes.

\begin{tabular}{lccc}
\hline \multirow{2}{*}{ Name of fungus } & \multicolumn{3}{c}{ MIC of test complex $(\mu \mathrm{g} / \mathrm{mL})$} \\
& $\mathrm{A}$ & $\mathrm{B}$ & $\mathrm{C}$ \\
\hline Aspergillus niger & 64 & 128 & 128 \\
Coniothyrium sp. & 64 & 128 & 128 \\
Tinea pedis & 80 & 160 & 160 \\
\hline $\mathrm{A}=\mathrm{K}[\mathrm{Cu}(\mathrm{SB}-1)(\mathrm{SCN})], \mathrm{B}=[\mathrm{Cu}(\mathrm{SB}-2) \mathrm{NN}], \mathrm{NN}=2$-aminopyridine, and \\
$\mathrm{C}=[\mathrm{Cu}(\mathrm{SB}-2)(\mathrm{NN})], \mathrm{NN}=2$-phenylenediamine.
\end{tabular}

antitumour agent bleomycin, which shows that cell growth inhibition is $94.90 \%$. The results are shown in Table 4 .

\subsection{Effect of Test Compounds on Survival Time of EAC Cell} Bearing Mice. It was found that treatment of tumour induced test animals with the compounds $\mathrm{A}, \mathrm{B}$, and $\mathrm{C}$ resulting in the increase of life span $35.70 \%, 16.98 \%$, and $22.32 \%$, respectively, when compared to control mice (life span 21.37 days). It was noticed that the anticancer antibiotic bleomycin increased the life span by $87.3 \%$ when compared to control. The results are shown in Tables 5 and 6.

4.3. Effect of Test Compounds and Bleomycin on Average Tumour Weight. Treatment of the test animals with test compounds, previously incubated with EAC cells, resulted in the inhibition of tumour growth. In case of treated group the body weight was growing slowly and by $53.99 \%, 46.78 \%$, and $51.46 \%$ less in compounds A, B, and C, respectively, compared to control group after 20 days of tumour inoculation. But in case of bleomycin, this value is $52.63 \%$ compared to control group. DMSO does not show any change of body weight compared to control group.

4.4. The Effect of Test Compounds on Hematological Parameters in Normal and Tumour Bearing Mice. Hematological parameters were studied in normal and tumour bearing mice. All were treated with test compounds for 12 days of tumour transplantation and after 12 days they were sacrificed and blood was collected for hematological examination. Number of mice were four. Results were shown in mean \pm SEM and compared with normal (without EAC bearing mice) and control (EAC bearing mice) group as shown in Table 7. 
TABLE 15: Result of antibacterial activity of test compounds.

\begin{tabular}{|c|c|c|c|c|}
\hline \multirow{2}{*}{ Test bacteria } & \multicolumn{3}{|c|}{ Diameter of zone of inhibition ( $\mathrm{mm}$ ) of test complexes } & \multirow{2}{*}{ Kanamycin (Ts/25 $\mu \mathrm{g} /$ disc) } \\
\hline & A & $\mathrm{B}$ & $\mathrm{C}$ & \\
\hline Bacillus subtilis & 7 & 5 & 4 & 16 \\
\hline Streptococcus- $\beta$-haemolytica & 13 & 9 & 7 & 25 \\
\hline Escherichia coli & 9 & 11 & 7 & 17 \\
\hline Sarcina lutea & 8 & 9 & 7 & 19 \\
\hline Klebsiella & 11 & 14 & 7 & 17 \\
\hline Shigella flexneri & 6 & 11 & 6 & 14 \\
\hline Shigella boydii & 9 & 26 & 8 & 24 \\
\hline Shigella dysenteriae & 12 & 10 & 9 & 14 \\
\hline Pseudomonas aeruginosa & 12 & 7 & 10 & 13 \\
\hline
\end{tabular}

$\mathrm{A}=\mathrm{K}[\mathrm{Cu}(\mathrm{SB}-1)(\mathrm{SCN})], \mathrm{B}=[\mathrm{Cu}(\mathrm{SB}-2) \mathrm{NN}], \mathrm{NN}=2$-aminopyridine, and $\mathrm{C}=[\mathrm{Cu}(\mathrm{SB}-2)(\mathrm{NN})], \mathrm{NN}=2$-phenylenediamine.

The growth of tumour in mice induced by EAC cells effect in acute anemic condition as indicated by the significant decrease of the $\mathrm{Hb} \%$ when compared to normal test animals under similar condition on day 12. The total white blood cell (WBC) count was also markedly decreased in the control group. In differential count of WBC, lymphocyte count was also found to be decreased and neutrophil count was increased on day 12 of tumour inoculation but no significant changes were observed in monocyte count on day 12 of the tumour inoculation as compared with normal mice. Effect of test compounds on hematological parameters of normal mice was also determined. No significant effect was found.

4.5. The Effect of Test Compounds on Serum Alkaline Phosphate Activity. Serum alkaline phosphatase activities were studied in normal and tumour bearing mice. Tumour bearing mice were treated with test compounds for 5 days of tumour transplantation and after 5 days they were sacrificed and blood was collected for determination of serum phosphatase. Serum alkaline phosphatase activity level in tumour bearing was decreased due to tumorigenesis when compared to the normal. Treatment with the test compounds restores the enzyme activity towards normal significantly. The serum alkaline phosphatase activity of the test compounds is shown in Table 8 .

4.6. Effect of Test Compounds on the Enhancement of Peritoneal Cells and Macrophages of Life. Treatment with the test compounds did not show any effect on the enhancement of number of peritoneal cells but the number of macrophages increased (Table 9).

4.7. The Effect of Test Compounds on Generation of MDA by Lipid Peroxidation in Serum of Normal Mice. Animals were treated with test compounds for 4 consecutive days. Sera from mice were collected on day 5 and malondialdehyde (MDA) concentration was measured. The dose of the test compounds $\mathrm{A}, \mathrm{B}$, and $\mathrm{C}$ was $8 \mathrm{mg} / \mathrm{kg}, 108 \mathrm{mg} / \mathrm{kg}$, and $168 \mathrm{mg} / \mathrm{kg}$, respectively. Effect of test compounds on normal mice showed that there was markedly increase in MDA, which indicated that there was release for free radical. The obtained data are shown in Table 10.

4.8. Histopathological Effect of Test Compounds. Ehrlich Ascites Carcinoma (EAC) cell inducing tumour at the site of injection was very prominent and showed fast growth, increased in size, and bulged out in skin. The histological feature shows necrosis at the centre and viable growing cells in the periphery. Some inflammatory reactions lymphocytic in nature with reduction of hair follicle were observed. The number of mitosis was observed which increases greatly. When treated with test compounds and bleomycin growth rate of tumour is reduced, inflammatory reaction has also increased to some extent (Table 11). Necrotic area is increased and hair follicles show their normal appearance.

4.9. Effect of Test Compounds on Total Protein in Peritoneal Fluid. Inoculation of Ehrlich Ascites Carcinoma (EAC) cell in peritoneal cavity causes accumulation of fluid, which is rich in protein. But when treated with test compounds, the protein present in the peritoneal fluid is reduced and fluids accumulate in the peritoneal cavity very slowly (Table 12).

\section{Antifungal Activity of the Test Compounds}

5.1. Zone of Inhibition of Antifungal Activity of Test Complexes. The antifungal activity of the test complexes against different fungi was investigated by using the doses of $80 \mu \mathrm{g} / \mathrm{disc}$, where standard antibiotic disc of Nystatin ( $45 \mu \mathrm{g} / \mathrm{disc})$ was used for comparison purpose. The diameter was evaluated $4 \mathrm{~mm}, 2 \mathrm{~mm}$, and $3 \mathrm{~mm}$ against tinea pedis; $8 \mathrm{~mm}, 23 \mathrm{~mm}$, and $10 \mathrm{~mm}$ against Aspergillus niger; $22 \mathrm{~mm}, 6 \mathrm{~mm}$, and $8 \mathrm{~mm}$ against Coniothyrium sp., respectively, for test complexes $\mathrm{A}, \mathrm{B}$, and $\mathrm{C}$ whereas diameter of zone of inhibition of Nystatin was found to be $18 \mathrm{~mm}, 28 \mathrm{~mm}$, and $20 \mathrm{~mm}$, respectively, against the organism. The antifungal activity (zone of inhibition) of the test complexes against respective fungi is presented in Table 13. The minimum inhibitory concentration (MIC) of the test complex A is $64 \mu \mathrm{g} / \mathrm{disc}$; for $\mathrm{B}$ and $\mathrm{C}$ it is $128 \mu \mathrm{g} /$ disc as listed in Table 14. 


\section{Antibacterial Activity of the Test Complexes}

6.1. The Result of Antibacterial Activity of Test Compounds. The antibacterial activity of the test complexes was determined by using the dose of $80 \mu \mathrm{g} / \mathrm{disc}$. The results of antibacterial activity measured in terms of zone of inhibition are shown in Table 15. The complexes showed minimum sensitivity against the following number of both Grampositive and Gram-negative bacteria and the results were compared with antibiotic disc of kanamycin.

The histopathological investigation on the tumour showed a retardation of tumour growth, increase in the narcotic and inflammatory area, and increased hair follicles. The Schiff complexes showed significant antimicrobial activity compared to control. We definitely say that the synthesized complexes possess cytotoxic properties. Toxicological studies revealed that the complexes are much more toxic to liver and kidney. They altered all biochemical parameters of rat blood. The exact mode of action of the complexes is unknown to us. Further investigation is appreciated to investigate detailed mechanism of action and their effect in serum electrolyte before any clinical use, especially for the effective doses.

\section{Conflict of Interests}

The authors declare that there is no conflict of interests regarding the publication of this paper.

\section{References}

[1] M. A. Ali and S. E. Livingstone, "Metal complexes of sulphurnitrogen chelating agents," Coordination Chemistry Reviews, vol. 13, no. 2-3, pp. 101-132, 1974.

[2] M. A. Ali, S. E. Livingstone, and D. J. Phillips, "Metal chelates of dithiocarbazic acid and its derivatives. VI. Antiferromagnetic and ferromagnetic interactions in some copper(II) complexes of salicylaldehyde and acetylacetone Schiff bases derived from s-methyldithiocarbazate," Inorganica Chimica Acta, vol. 7, pp. 179-186, 1973.

[3] M. A. Ali and R. N. Bose, "Transition metal complexes of furfural and benzil schiff bases derived from S-benzyldithiocarbazate," Polyhedron, vol. 3, no. 5, pp. 517-522, 1984.

[4] S. Kumar, D. N. Dhar, and P. N. Saxena, "Applications of metal complexes of schiff bases-a review," Journal of Scientific and Industrial Research, vol. 68, no. 3, pp. 181-187, 2009.

[5] T. Punniyamurthy, S. J. S. Kalra, and J. Iqbal, "Cobalt(II) catalyzed biomimetic oxidation of hydrocarbons in the presence of dioxygen and 2-methylpropanal," Tetrahedron Letters, vol. 36, no. 46, pp. 8497-8500, 1995.

[6] L. Messori, F. Abbate, G. Marcon et al., "Gold(III) complexes as potential antitumor agents: solution chemistry and cytotoxic properties of some selected gold(III) compounds," Journal of Medicinal Chemistry, vol. 43, no. 19, pp. 3541-3548, 2000.

[7] M. T. H. Tarafder, K. Fatema, and M. A. J. Miah, "Thiocyanato complex of $\mathrm{Ni}(\mathrm{II}), \mathrm{Co}(\mathrm{II})$, and $\mathrm{Zn}(\mathrm{II})$ inos containing some bidentate neutral auxiliary," Journal of the Bangladesh Chemical Society, vol. 2, no. 1, pp. 47-50, 1989.
[8] M. T. H. Tarafder and K. Fatema, "Synthesis and characterization of some thiocyanato complexes of $\mathrm{Ni}(\mathrm{II}), \mathrm{Zn}(\mathrm{II}), \mathrm{Pd}(\mathrm{II})$, $\mathrm{Cd}(\mathrm{II}), \mathrm{Cu}(\mathrm{I})$ and $\mathrm{Co}(\mathrm{II})$ containing auxillary ligands $\mathrm{PPh}_{3}$, $\mathrm{OPPh}_{3}, \mathrm{C}_{5} \mathrm{H}_{5} \mathrm{~N}, \mathrm{C}_{5} \mathrm{H}_{5} \mathrm{NO}$, and $\mathrm{OAsPh}_{3}$, analysis of the acceptor properties of the metal ions in the above complexes," Journal of the Bangladesh Chemical Society, vol. 1, pp. 77-79, 1988.

[9] M. T. H. Tarafder and R. N. Bose, "Thiocyanato complexes of $\mathrm{Zr}(\mathrm{IV}), \mathrm{Th}(\mathrm{IV}), \mathrm{Cr}(\mathrm{III})$ and $\mathrm{U}(\mathrm{VI})$ containing auxillary ligands $\mathrm{ONC}_{5} \mathrm{H}_{5}, \mathrm{OAsPPh}_{3}$, and $\mathrm{NC}_{5} \mathrm{H}_{5}$, analysis of the acceptor properties of the metal ions in the above complexes," Journal of the Bangladesh Chemical Society, vol. 1, pp. 59-61, 1988.

[10] L. A. Banu, M. S. Islam, M. A.-A. Al-Bari, and M. KudratE-Zahan, "Synthesis and characterization with antibacterial, antifungal, cytotoxicity studies on the Co (II), Ni(II) AND $\mathrm{Cu}(\mathrm{II})$ complexes of tridentate ONO coordinating schiff bases and heterocyclic amines," Int. J. Rec. Adv. Multi. Res, vol. 2, no. 1, pp. 145-148, 2015.

[11] M. Kudrat-E-Zahan, M. M. Haque, L. Ahmmed, M. S. Ali, and M. S. Islam, "Studies on the mixed ligand complexes of Co(II), $\mathrm{Ni}(\mathrm{II})$ and $\mathrm{Cu}(\mathrm{II})$ with Phthalimide and eterocyclic amines," International Journal of Materials Science and Applications, vol. 4, no. 2, pp. 120-123, 2015.

[12] M. Kudrat-E-Zahan, M. S. Islam, and M. Abul Bashar, "Synthesis, characteristics, and antimicrobial activity of some complexes of $\mathrm{Mn}(\mathrm{II}), \mathrm{Fe}(\mathrm{III}) \mathrm{Co}(\mathrm{II}), \mathrm{Ni}(\mathrm{II}), \mathrm{Cu}(\mathrm{II})$, and $\mathrm{Sb}(\mathrm{III})$ containing bidentate Schiff base of SMDTC," Russian Journal of General Chemistry, vol. 85, no. 3, pp. 667-672, 2015.

[13] W. J. Geary, "The use of conductivity measurements in organic solvents for the characterisation of coordination compounds," Coordination Chemistry Reviews, vol. 7, no. 1, pp. 81-122, 1971.

[14] M. Akbar Ali and M. T. H. Tarafdar, "Metal complexes of sulphur and nitrogen-containing ligands: complexes of sbenzyldithiocarbazate and a schiff base formed by its condensation with pyridine-2-carboxaldehyde," Journal of Inorganic and Nuclear Chemistry, vol. 39, no. 10, pp. 1785-1791, 1977.

[15] M. T. H. Tarafder and M. A. Ali, "Chelates of nickel(II) and copper(II) with tridentate Schiff base formed by the condensation of S-benzyldithiocarbazate with benzoin," Canadian Journal of Chemistry, vol. 56, no. 15, pp. 2000-2002, 1978.

[16] Md. Kudrat-E-Zahan and M. S. Islam, "Characterization, and antimicrobial activity of complexes of $\mathrm{Cu}(\mathrm{II}), \mathrm{Ni}$ (II), $\mathrm{Zn}$ (II), $\mathrm{Pb}(\mathrm{II}), \mathrm{Co}(\mathrm{II}), \mathrm{Mn}(\mathrm{II})$, and U(VI) containing bidentate Schiff base of [S-methyl-3-(4-methoxybenzylidine)dithiocarbazate]," Russian Journal of General Chemistry, vol. 85, no. 4, pp. 979983, 2015.

[17] N. J. Destefano and J. L. Burmeister, "Cooperative electronic ligand effects in pseudohalide complexes of rhodium(I), iridium(I), gold(I), and gold(III)," Inorganic Chemistry, vol. 10, no. 5, pp. 998-1003, 1971.

[18] M. T. H. Tarafder, M. A. Jalil Miah, R. N. Bose, and M. Akbar Ali, "Metal complexes of some Schiff bases derived from S-benzyldithiocarbazate," Journal of Inorganic and Nuclear Chemistry, vol. 43, no. 12, pp. 3151-3157, 1981.

[19] M. T. H. Tarafder and M. A. K. Bodruddoza, “Thiocyanato complexes of $\mathrm{Mg}$ (II) and $\mathrm{Ca}$ (II) containing some bidentate auxillary ligands," Journal of the Bangladesh Chemical Society, vol. 4, no. 2, pp. 159-162, 1991. 

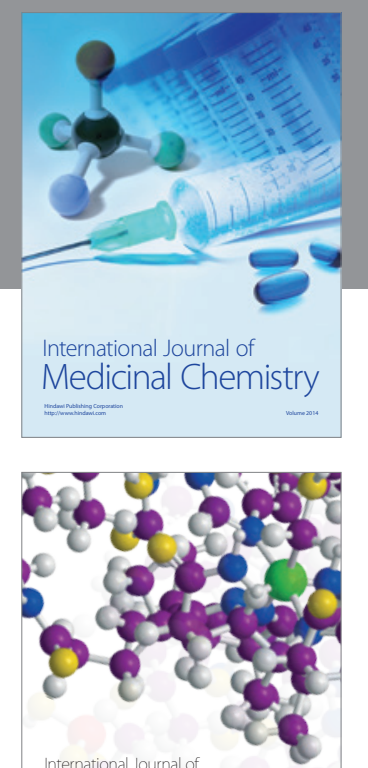

\section{Carbohydrate} Chemistry

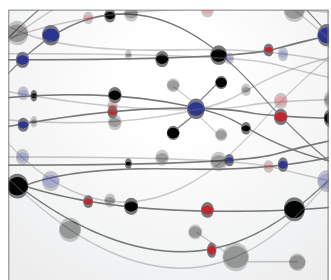

The Scientific World Journal
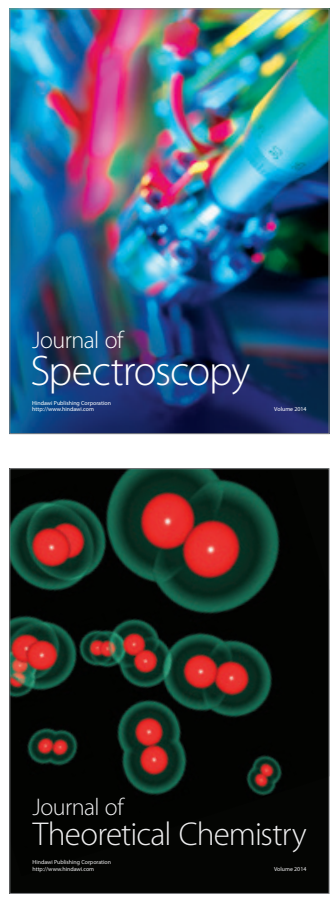
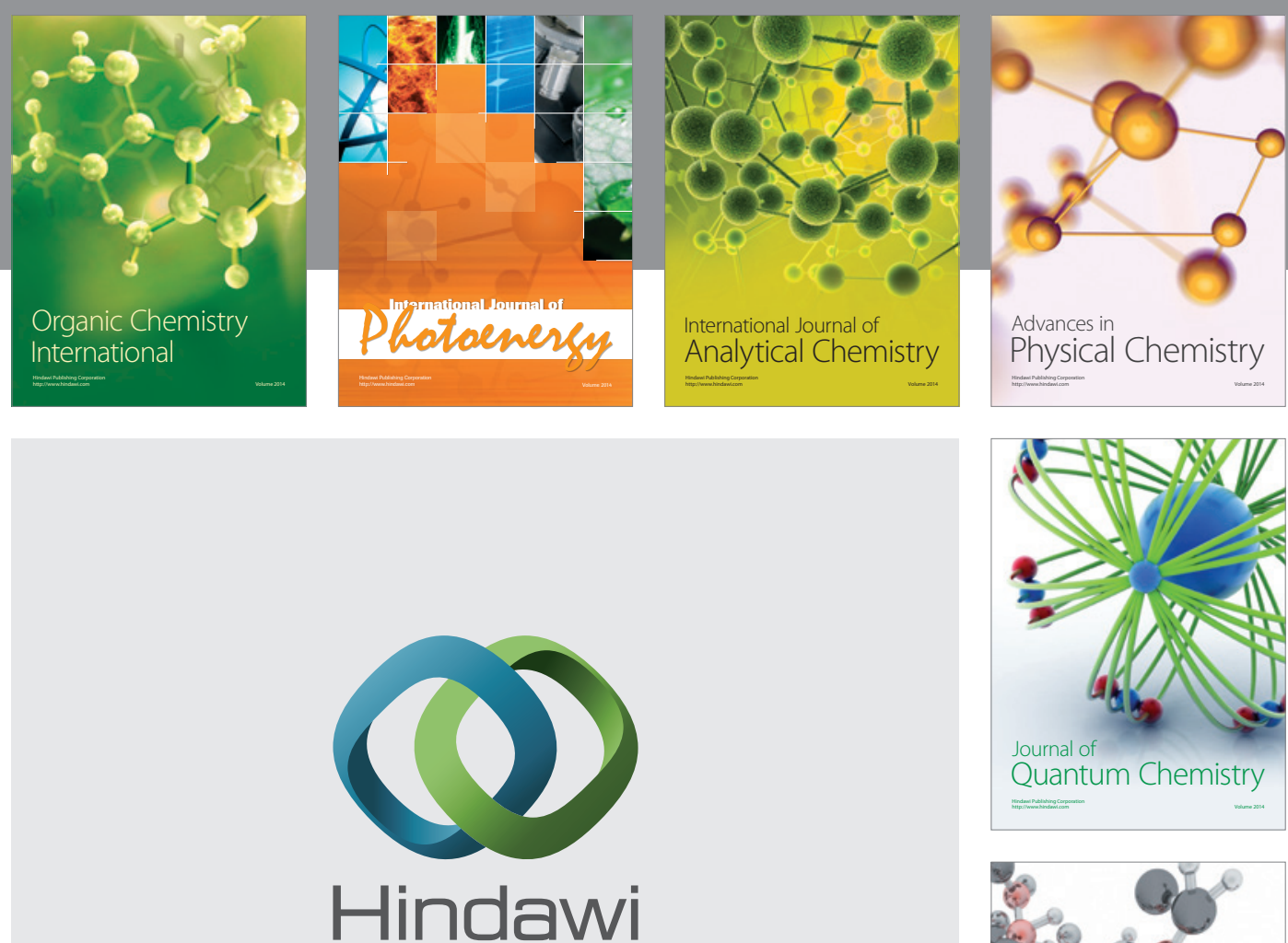

Submit your manuscripts at

http://www.hindawi.com

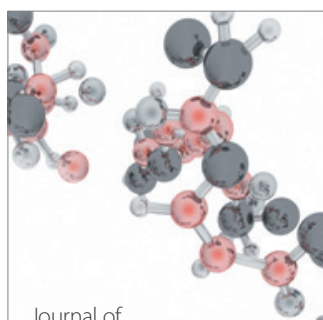

Analytical Methods

in Chemistry

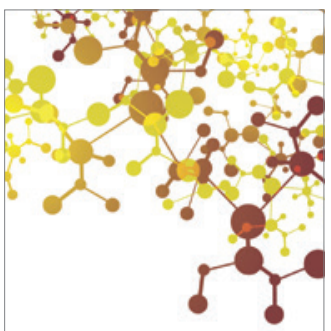

Journal of

Applied Chemistry

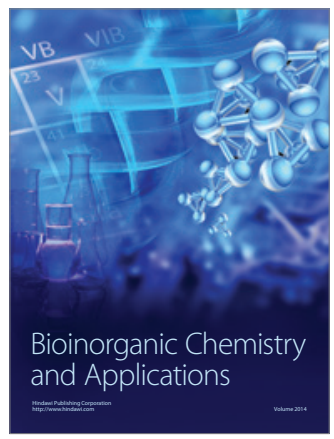

Inorganic Chemistry
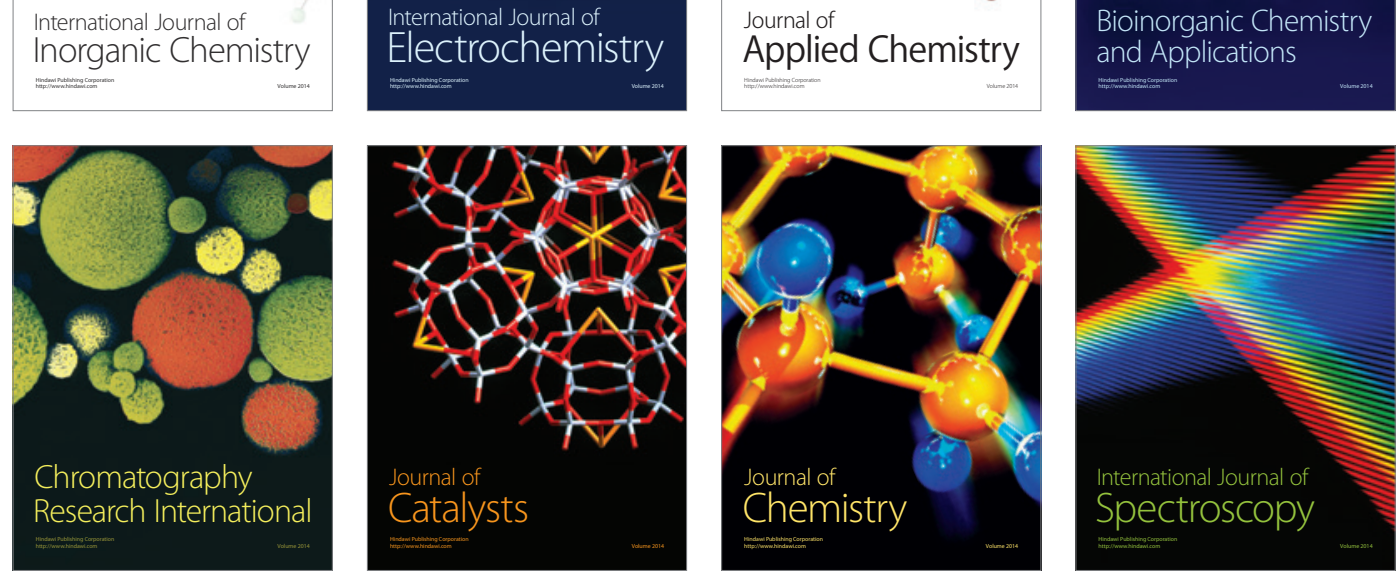